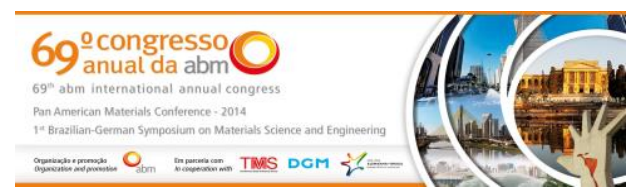

Theme: Corrosion

\title{
CHARACTERIZATION OF SMART PAINT IN PROTECTION AGAINST CORROSION*
}

\author{
Rodrigo Sanchotene Silva ${ }^{1}$ \\ Vitor Maggi \\ Jane Zoppas Ferreira ${ }^{3}$ \\ Álvaro Meneguzzi
}

\begin{abstract}
Currently the industries of paint have directed their efforts on cleaner production of products that provide effective performance in corrosion protection of metallic materials. This work search introduce a new alternative of organic coating, without the presence of hazardous metals and replace equipments commercials used method of anodic protection for protection of oxidized metals. From this it, was produced Smart Paint (SP), consisting of Paint Acrylic Commercial (PAC) mixed the $1 \%$ of binder, compound by the conducting polymer, Polyaniline Emeraldine Base (PAni EB) and plasticizer 4-chloro-3-methylphenol. The SP and PAC were applied to plates of carbon steel AISI 1010, with the aid of dip coat technique and then were subjected to drying for $48 \mathrm{~h}$. The SP was characterized by thermals and physicochemical analyzes in order to verify possible changes in chemical properties of the ink produced, beyond perform electrochemical tests of Open Circuit Potential and Electrochemical Impedance Spectroscopy, employing equipment Potentiostat/Galvanostat Autolab PGSTAT302 Ecochemie, and aqueous 2 mol.L-1 of $\mathrm{H}_{2} \mathrm{SO}_{4}$. The results obtained allow us to state that the plasticizer does not alter the electrochemical properties of PAni and application of binder PAni EB to PAC does not alter the physicochemical properties of commercial coating. The binder PAni EB adds to PAC the capacity to induce the formation or maintenance of protective oxides in oxidizable metals submitted to harsh environments, method known as anodic corrosion protection.
\end{abstract}

Keywords: Corrosion; Organic coating; Anodic protection; Binder.

PhD student, Engineering, PPGE3M, UFRGS, Porto Alegre, RS, Brazil.

Undergraduate, Engineering of Materials, DEMAT, UFRGS, Porto Alegre, RS, Brazil.

$P h D$ in Engineering, DEMAT, PPGE3M, UFRGS, Porto Alegre, RS, Brazil.

* Technical contribution to the $69^{\text {th }}$ ABM International Annual Congress and to the ENEMET, July $21^{\text {st }}-25^{\text {th }}$, 2014, São Paulo, SP, Brazil. 


\section{INTRODUCTION}

The industries of protective organic coatings have sought in recent years the development and production of inks that cause less environmental impact and a corrosion protection effective of metallic materials [1]. Over the years, laws and environmental regulations have increasingly introduced restrictions on the use of toxic chemical elements $(\mathrm{Zr}, \mathrm{Cr}, \mathrm{Zn}, \mathrm{Pb}, \mathrm{Cd}$ and others) to produce anticorrosive paints due to potential impacts to the environment and health human. Moreover, the mechanism of protection provided by these jackets can be combined with other methods such as anodic protection that requires application of impressed current, i.e., the use of rectifier equipment that have a high consumption of electricity, for the passivation of metal interest [2,3].

The use of organic coatings such as paints are alternatives that can be used to combat corrosion of metallic materials, because can act as a physical barrier, preventing physical contact between the metal and the electrolyte and be associated with other protection methods [4]. The use of anticorrosive paints is consolidated into two main mechanisms: forming a homogeneous film capable of prevent infiltration of aqueous solutions containing aggressive ions $\left(\mathrm{H}_{2} \mathrm{SO}_{4}, \mathrm{HCl}\right.$, etc.) with or without the presence of oxygen and contain constituents (pigments, resins or cargo) that provide specific protection mechanisms, such as anodic or cathodic protection to the metal substrate [4-6].

The intrinsically conducting polymer (ICP), as Polyaniline Emeraldine Base (PAni EB) nonconductive, represent a new option of constituents for the production of protective organic coatings, because presents specific characteristics, such as low electronic conductivity and/or ionic in respect to the Polyaniline Emeraldine Protonated (PAni EP) conductor, aspect which indicates a low diffusion of metal ions into the metal/coating/electrolyte system, which assists the barrier effect generated by the film formed by the ink constituted of PAni EB. Furthermore, the PAni EB mixed with plasticizers has the ability to form free-standing films or resins that can form films or formulate organic coatings with sufficient cohesion for application to a metal surface $[4,7,8]$.

This work has as objective the development of a Smart Paint (SP) that can optimize the physical contact between the electrolyte/PAni $E B / m e t a l$ system, causing is maximized the electrochemical capacity of the ICP for the formation or maintenance of passivation in AISI 1010 steel. Moreover, the formulation of an anticorrosive SP is a proposed replacement for anticorrosive coatings or methods that have the greatest environmental impact.

With this, was performed in this study the production of a SP, from of the mixture of a Paint Acrylic Commercial (PAC) a binder that is composed of PAni EB, an electrochemically inert plasticizer, 4-chloro-3-methylphenol (CMP) and to control the viscosity and dispersion, the organic solvent dichloromethane $\left(\mathrm{CH}_{2} \mathrm{Cl}_{2}\right)$. The SP was subjected to tests physicochemical characterization of Thermogravimetric Analysis (TGA) and Differential Scanning Calorimetry (DSC). The paint produced and PAC were applied on AISI 1010 steel plates and subjected to electrochemical tests of Open Circuit Potential (OCP) and Electrochemical Impedance Spectroscopy (EIS), which seek to investigate the performance of SP in relationship to PAC and the capacity of formulated paint in promote anodic protection in aggressives environments, such as aqueous $2 \mathrm{~mol}^{-1} \mathrm{~L}^{-1} \mathrm{H}_{2} \mathrm{SO}_{4}$.

\footnotetext{
* Technical contribution to the $69^{\text {th }}$ ABM International Annual Congress and to the ENEMET, July $21^{\text {st }}-25^{\text {th }}$, 2014, São Paulo, SP, Brazil.
} 


\section{MATERIAL AND METHODS}

\subsection{Surface Preparation of Steel AISI 1010}

The AISI 1010 steel plates used in this work were produced by cold rolling and subsequently coated with protective oil in order to inhibit the initial presence of corrosion. The samples of dimensions $50 \times 100 \times 1 \mathrm{~mm}$ were subjected to the alkali degreasing process, with the immersion in Saloclean $619 \mathrm{~L}$ solution at the concentration of $5 \% \mathrm{w} / \mathrm{v}$, at a temperature of $45^{\circ} \mathrm{C}$ for a period of $15 \mathrm{~min}$. After, was performed washing the parts with jets of deionized water and drying with jet air to the approximate temperature of $60{ }^{\circ} \mathrm{C}$. The plates free of impurities and were intended for the application of the PAC and SP, and subsequently, subjected to electrochemical analysis [8].

\subsection{Production and Application of Binder PAni EB and SP}

The production of SP was started with the formulation of the binder PAni EB, which occurred from the mixture of PAni EB to the CMP plasticizer and organic solvent dichloromethane $\left(\mathrm{CH}_{2} \mathrm{Cl}_{2}\right)$, the mass ratio 1:2:10, respectively. The elements were mixed under intense agitation with the use of high speed disperser Dispermat Model $\mathrm{N} 1$ in closed bottle for $2 \mathrm{~h}$, with the objective of homogenize the solution until the pour point that allowing association with the PAC [9].

From this, the mixture was held at $1 \%$ concentration of binder PAni EB of the PAC, with the aid of the ball mill equipment Dispermat SL, using zirconium balls in rotation speed of $1000 \mathrm{rpm}$ for a period of $30 \mathrm{~min}$, the solution was homogenized for subsequent application.

The PAC (without binder PAni) and SP were applied to AISI 1010 steel plates, through the technique of applying dip coat, with the use of equipment Deep Coating Elevador de Disco MA 765-Marconi, where immersion speed used was $300 \mathrm{~mm} / \mathrm{s}$, the immersion time of 10 and the output speed of $300 \mathrm{~mm} / \mathrm{s}$. After the samples were dried during $48 \mathrm{~h}$ at room temperature.

\subsection{Thermal Analyzes}

The samples used in DSC and TGA analyzes were obtained from the application of the binder PAni, the PAC and SP on boards plan and nonadherent glass, allowing evaporation of the solvent and the formation of self-supporting films. TGA was performed using the equipment Thermogravimetric Analyzer Model Q50 from TA Instruments, and the temperature range used was 25 at $875^{\circ} \mathrm{C}$ under $\mathrm{N}_{2}$. The heating rate used for all samples was $20^{\circ} \mathrm{C} / \mathrm{min}$.

The DSC analyzes was performed using the instrument TA Instruments DSC Model Q20, the heating rate of $10^{\circ} \mathrm{C} / \mathrm{min}$, with a flow of $\mathrm{N}_{2}$ into the kiln system in order to protect the equipment.

\subsection{Electrochemical Analyzes}

The electrochemical tests of OCP and EIS were performed with the use of threeelectrode electrochemical cells, containing as working electrode the AISI 1010 steel with or without coating (PAC or SP), reference electrode the $\mathrm{Ag} / \mathrm{AgCl}$ and as auxiliary electrode the $\mathrm{Pt}$ wire of $99.99 \%$. The assays were developed in the harsh

\footnotetext{
* Technical contribution to the $69^{\text {th }}$ ABM International Annual Congress and to the ENEMET, July $21^{\text {st }}-25^{\text {th }}$, 2014, São Paulo, SP, Brazil.
} 


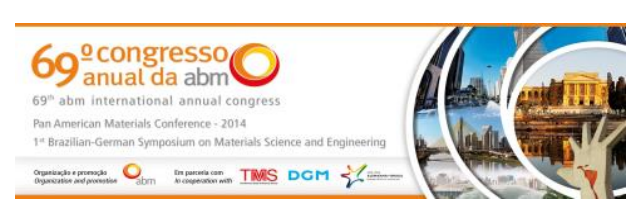

environment of $\mathrm{H}_{2} \mathrm{SO}_{4}$ in the concentration 2 mol.L-1, with the aid of equipment Potentiostat/Galvanostat AUTOLAB PGSTAT 302 Ecochemie and softwares GPES and FRA, shown in figure 1.

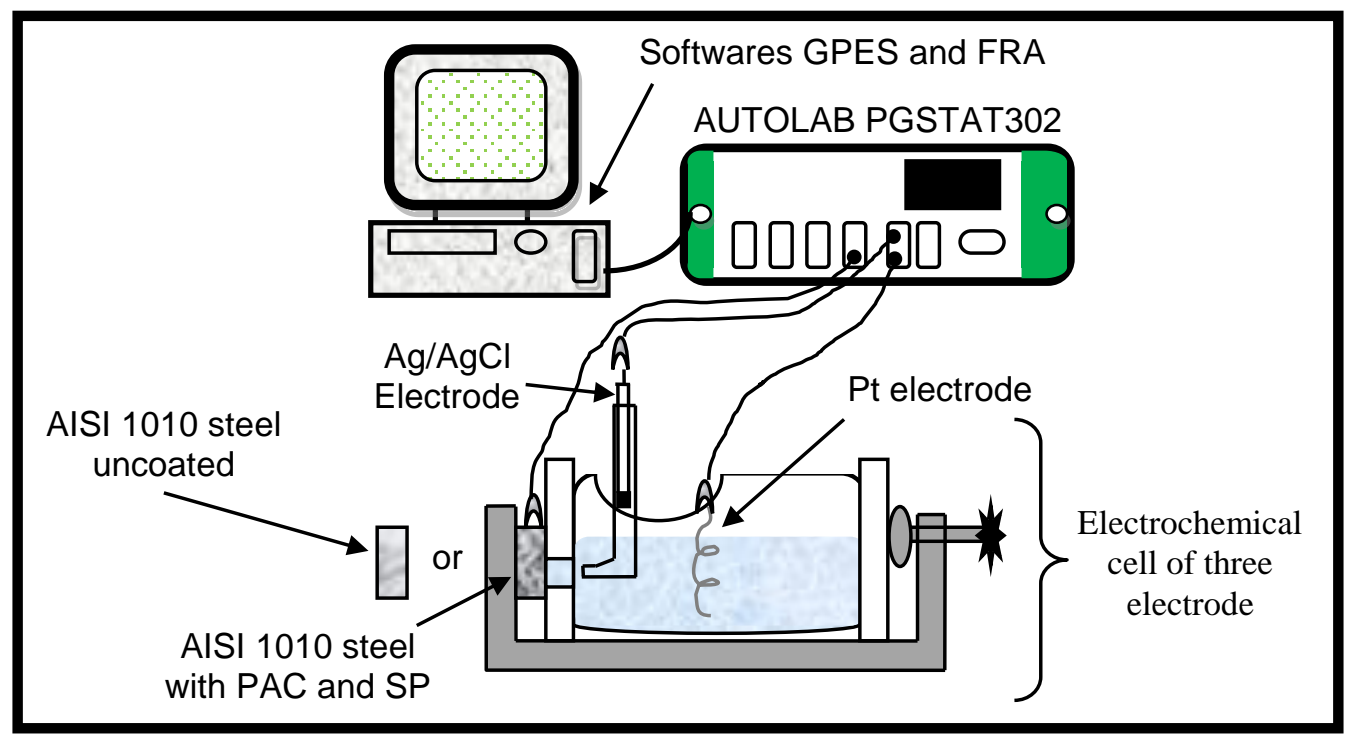

Figure 1. Representation of the structure necessary for the analyzes of OCP and EIS.

\section{RESULTS AND DISCUSSION}

\subsection{Thermal Analyzes}

\subsubsection{TGA}

TGA assays utilized the initials weights of $10.204 \mathrm{mg}$ film of binder PAni EB, 9.922 $\mathrm{mg}$ of PAC and $10.532 \mathrm{mg}$ of SP, formed from the evaporation of the solvent. The film of binder PAni EB, according to figure 2, showed an initial loss of $2.3 \%$ weight until the temperature of $150^{\circ} \mathrm{C}$, which can be attributed to loss of moisture acquired by exposure to the environment. The temperature interval of $100^{\circ} \mathrm{C}$ to $200^{\circ} \mathrm{C}$ occurs the loss of $27 \%$ of weight, due to almost total loss of weight CMP. Thereafter, the weight loss reaches $55 \%$ until the temperature of $670{ }^{\circ} \mathrm{C}$, but in the elapse this temperature interval was observed variations of weight loss, aspect that can be attributed to structural decomposition of PAni. Have the interval 670 and $875^{\circ} \mathrm{C}$ occur weight loss $5 \%$, due to degradation fragments chair PAni, resulting $39 \%$ of the initial mass at the end of the experiment. $[8,10,11$.

According to figure 2, the samples of SP and PAC presented approximate weight losses of $1 \%$, which can be associated with the presence of moisture in both samples. The interval of temperature of 150 to $250^{\circ} \mathrm{C}$, the SP and the PAC presented weight losses approximate the 34.92 and $36.22 \%$, respectively, that may represent the structural degradation of organic coatings and more specifically to the SP, may have occurred the almost total evaporation of the CMP contained in the binder PAni EB. $[8,12]$. The analysis at the reach the temperature of $450^{\circ} \mathrm{C}$, shall a slowdown of weight loss of SP and PAC, which can be attributed to structural decomposition of the polymer forming the acrylic resin. The interval of temperature $450-850^{\circ} \mathrm{C}$, the SP and the PAC have a constant residual mass loss, including degradation of the polymeric chains of PAni contained in the SP.

\footnotetext{
* Technical contribution to the $69^{\text {th }}$ ABM International Annual Congress and to the ENEMET, July $21^{\text {st }}-25^{\text {th }}$, 2014, São Paulo, SP, Brazil.
} 

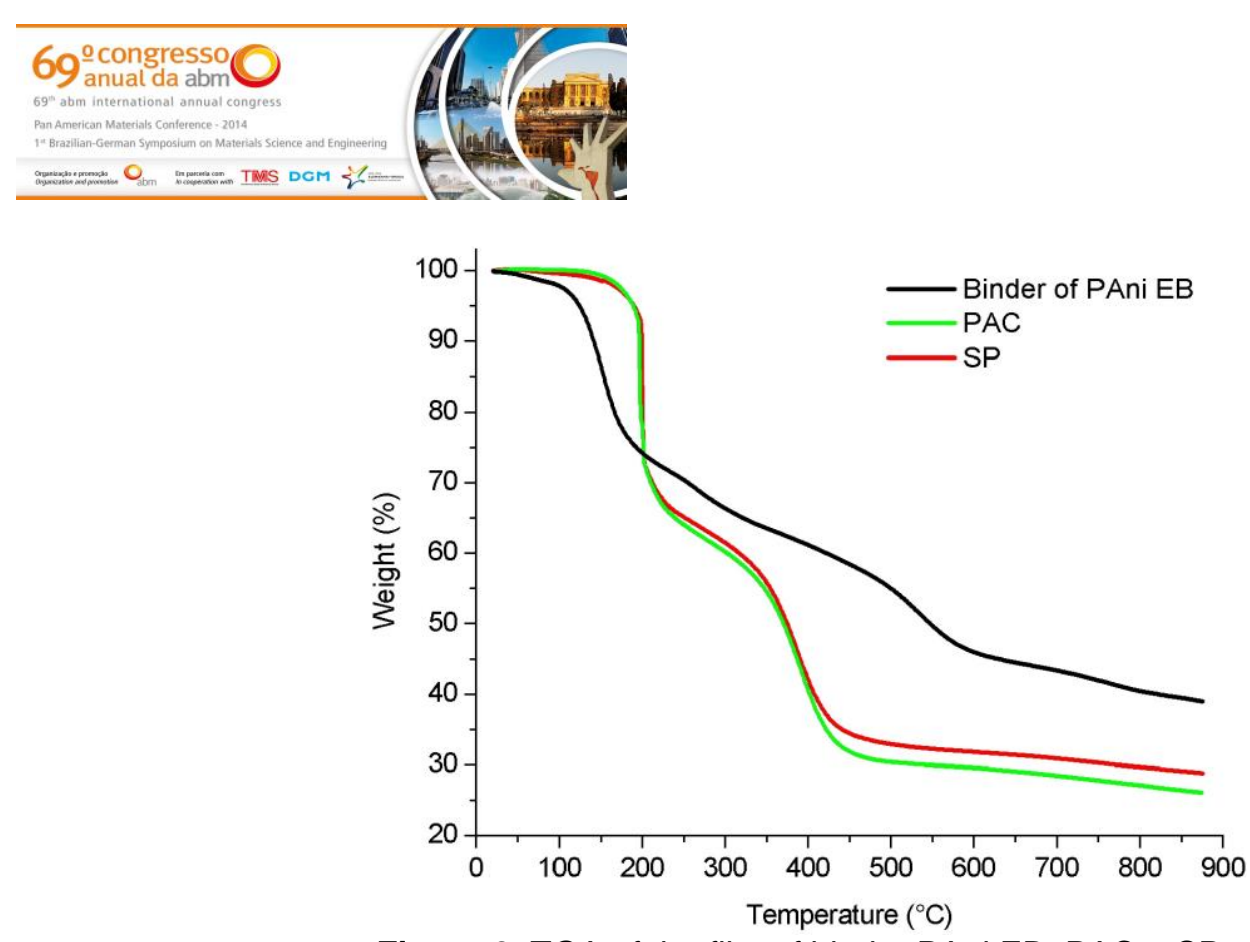

Figure 2. TGA of the film of binder PAni EB, PAC e SP.

The characterization by TGA showed the low physical-chemical interaction of the binder PAni EB to PAC for the formation of SP, because despite the concentration low $(1 \%)$, the results presented were consistent, especially in the interval of temperature $150-450{ }^{\circ} \mathrm{C}$, where there is the presence of the binder with part of its components. This result allows us to indicate the SP is formed by the evaporation of the solvent, and after this process, their components maintains their thermal and chemical property.

\subsubsection{DSC}

DSC analysis used with the intention of investigating and analyzing the thermal characteristics of the film of PAni EB, PAC and SP, occured from room temperature to $200{ }^{\circ} \mathrm{C}$, the use of initials weights of $3.10 \mathrm{mg}$ of PAni EB film, $5.10 \mathrm{mg}$ of PAC and $4.90 \mathrm{mg}$ of SP.

According to figure 3, the film of PAni EB presents an endothermic peak near to the temperature of $86^{\circ} \mathrm{C}$, which can be attributed to loss of moisture contained in the film and/or remnants of $\mathrm{CH}_{2} \mathrm{Cl}_{2}$ used in the ICP dispersion [13]. The peak in the temperature of $161.5^{\circ} \mathrm{C}$, represents is the displacement of the exothermic peak of PAni EB, which is associated at the onset of melting of the CMP which occurs near the temperature of $65^{\circ} \mathrm{C}[9,13]$.

Samples of PAC and SP, verified in figure 3, presented a flow heat constant during the DSC analysis, aspect that can be checked until the temperature of $155^{\circ} \mathrm{C}$, where only the sample of SP presents an exothermic peak of heat flux which, which can be attributed to partial melting and, subsequent, partial boiling of the plasticizer CMP $[9,13]$. After, at temperatures above $165^{\circ} \mathrm{C}$ it was possible to observe the beginning of an exothermic peak for the sample of PAC and SP, which must correspond at the process of structural degradation of organic coatings.

\footnotetext{
* Technical contribution to the $69^{\text {th }}$ ABM International Annual Congress and to the ENEMET, July $21^{\text {st }}-25^{\text {th }}$, 2014, São Paulo, SP, Brazil.
} 


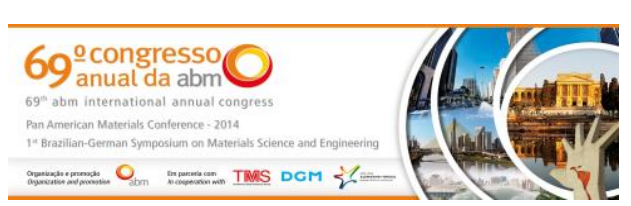

aggressive environment, through the anodic protection mechanism for a certain period.
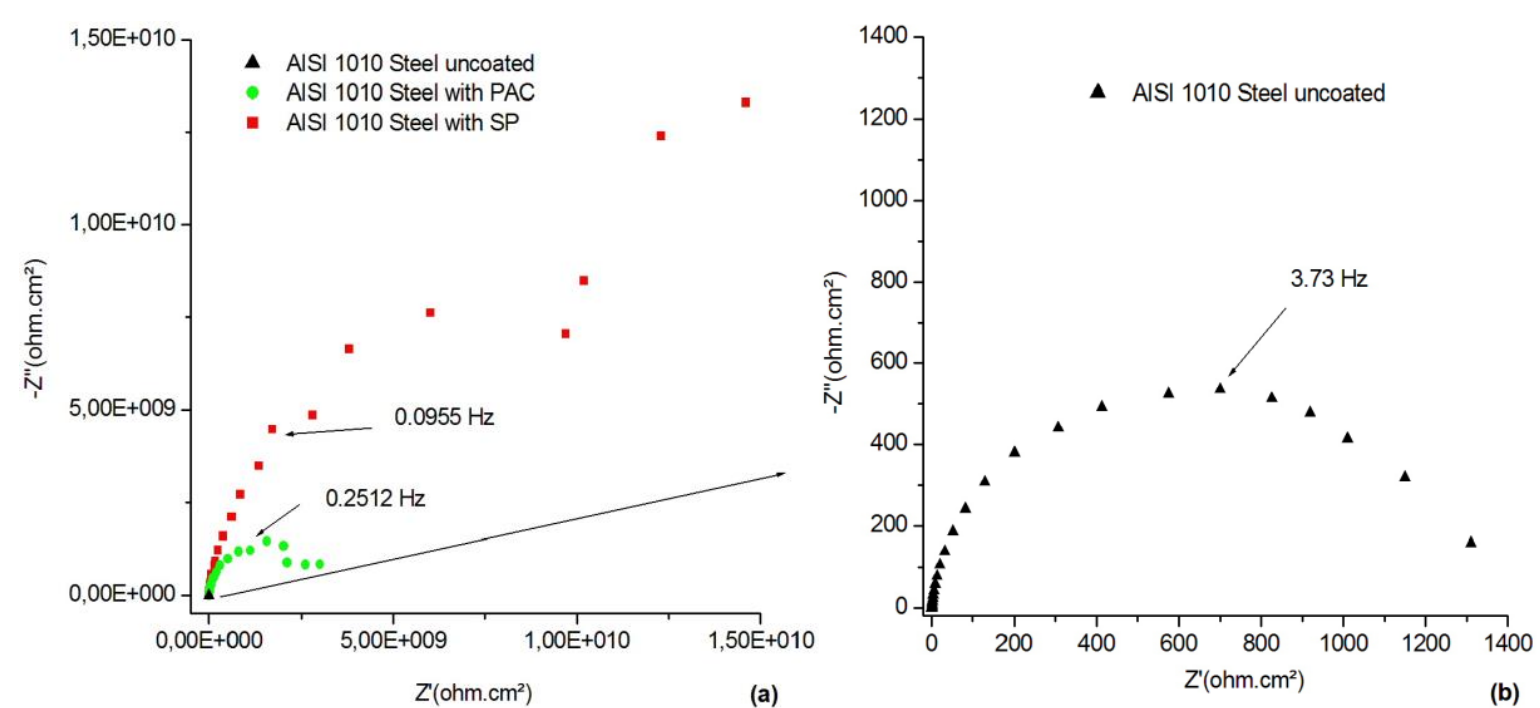

Figure 6. EIS of AISI 1010 steel coated with PAC and SP (a); AISI 1010 steel uncoated (b).

As figure 6ab, assays of EIS were represented by Nyquist diagrams with frequency sweep from $10^{-2}$ to $10^{5} \mathrm{~Hz}$. The figure $6 \mathrm{~b}$ shows the Nyquist diagram for AISI 1010 steel uncoated, where we observed an arc with value resistance in the order 1400 $\Omega . \mathrm{cm}^{2}$. This spectrum demonstrates that the sample is being subjected to the corrosion process, because its open circuit potential is fixed at the $-0.41 \mathrm{~V}(\mathrm{Ag} / \mathrm{AgCl})$ [14]. Figure $6 a$ shows the diagram obtained by plate containing PAC, where was possible observed an arc with resistance value of order higher than that of the uncoated sample, which indicates that the PAC provides an obstacle in the electrolyte / metal interaction, probably due the effect barrier of protection, but is in a range of potential $\left(+0.28 \mathrm{~V}_{(\mathrm{Ag} / \mathrm{AgCl})}\right)$ where still the oxidation of the metal occurs.

The analysis of EIS in sample coated by SP verified in figure $6 \mathrm{a}$, held during the potential 0 at $+0.59 \mathrm{~V}(\mathrm{Ag} / \mathrm{AgCl})$, can be divided into frequencies bands, where there is initially a semicircle at high frequency representing the process interfacial charge transfer between electrolyte/coating/metal system, possibly from by reducing ICP and oxidation of the steel.

The other frequency range represents frequencies midrange that can be attributed to ionic diffusion of dopants ions of $\mathrm{HSO}_{4}$ - of the solution to PAni contained in the coating, causing the ICP is protonated. The last band represents the lows frequencies, indicated by a sketch of upward vertical line which indicates that the diffusion of ions was ceased, possibly by the presence of ferric oxides generated by the protective action of PAni, which allows the increased resistance to the flow of electrons and consequently the metal protection $[9,14,15]$.

\section{CONCLUSION}

The research for the development and production of SP formed by mixing of a PAC an binder containing the ICP PAni EB and a chemically inert plasticizer such as CMP, showed responses that confirming its performance possible in inhibiting corrosion. Thermal analysis TGA and DSC demonstrated the low physical-chemical interaction of the binder PAni EB to formation of the SP, and that the presence of the ICP associated with CMP and subsequently, an commercial polymeric matrix does

\footnotetext{
* Technical contribution to the $69^{\text {th }}$ ABM International Annual Congress and to the ENEMET, July $21^{\text {st }}-25^{\text {th }}$, 2014, São Paulo, SP, Brazil.
} 


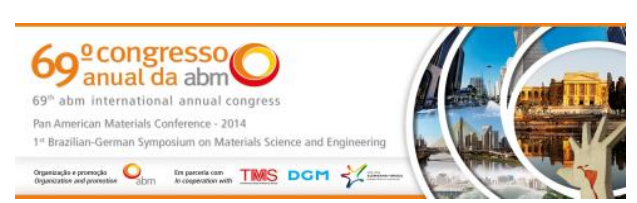

not changes its electrochemical properties, that has objective the production of passivation of oxidizable steels.

Electrochemical tests of OCP and EIS indicate that the presence of the binder results in the formation of obstacle, protectors probably oxides characteristic of the anodic protection, that associated to barrier produced by the organic coating decreases or inhibit significantly the processes of oxidation and reduction characteristic of corrosion in environments aggressive, through anodic protection for a minimum of $5000 \mathrm{~s}$.

With this, the use of CMP and PAni EB in the formation of SP, showed with an option to lower environmental impact in the production of anticorrosive paints, promoting the replacement of toxic metals in their composition and rectifiers equipment that consumes large amounts of energy.

\section{Acknowledgments}

The authors thank CNPq (Project 159262/2011-9) and CAPES.

\section{REFERENCES}

1 Molinari MA, Quelhas OLG, Filho APN. Avaliação de oportunidades de produção mais limpa para a redução de resíduos sólidos na fabricação de tintas. Prod. 2013:23(2): 364-374.

2 Shao $Y$, Jia C, Meng G, Zhang T, Wang F. The role of zinc phosphate pigment in the corrosion of scretched epoxy-coated steel. Cor Scien. 2009:51(2): 371-379.

3 Baeckmann WV, Schwenk W, Prinz W. Handbook of Cathodic Corrosion Protection: Theory and Practice of Eletrochemical Protection Processes. Edition Third. Burlington: Elsevier; 1997.

4 Wicks JrZW, Jones FN, Pappas SP, Wicks DA .Organic Coatings: science and technology. New Jersey: John Wiley \& Sons; 2007.

5 Coelho LR. Guia Técnico Ambiental tintas e vernizes: série P+L. São Paulo: CETESB; 2008.

6 Wáskiewicz S, Zenkner K, Langer E, Lenartowicz M, Gajlewicz I. Organic coatings based on new Schiff base epoxy resins. Prog. Org. Coat. 2013:76(7-8):1040-1050.

$7 \quad$ Plieth W. Electrochemistry for Materials Science. Elsevier; 2008.

8 Silva RS, Cardozo HM, Ferreira JZ, Ferreira CA, Meneguzzi A. Filme Autosuportado de Polianilina Desdopada para Aplicações Anticorrosivas. Polím. 2012:22(3):288-294.

9 Silva RS. Binder a Base de Polianilina para a Proteção Anódica de Aço Carbono [Dissertation of Master of Engineering]. Porto Alegre: UFRGS; 2011.

10 Alves WF, Venancio EC, Leite FL, Kanda DHF, Malmonge LF, Malmonge JA, Mattoso LHC. Thermo-analyses of polyaniline and its derivatives. Thermochim. Act. 2010: 502(1-2):43-46.

11 Gupta G, Birbilis N, Cook AB, Khanna AS. Polyaniline-Lignosulfonate/epoxy coating for corrosion protetion of AA2024-T3. Cor. Scien. 2013: 67:256-267.

12 Topçuoglu O, Altinkaya SA, Balkose D. Characterization of waterborne acrylic based paint films and measurement of their water vapor permeabilities. Prog. in Org.Coat. 2006:56(4):269-278.

13 Ding L, Wang X, Gregory RV. Thermal properties of chemically synthesized polyaniline (EB) powder. Synth. Met. 1999:104(2):73-78.

14 Osaka T, Momma T. Impedance Analysis of Electropolymerized Conducting Polymers for Polymer Battery Cathodes. Electrochim. Act.1993:38(14), 2011-2014.

15 Wolynec S. Técnicas eletroquímicas em Corrosão. São Paulo: Editora da Universidade de São Paulo, 2003.

\footnotetext{
* Technical contribution to the $69^{\text {th }}$ ABM International Annual Congress and to the ENEMET, July $21^{\text {st }}-25^{\text {th }}$, 2014, São Paulo, SP, Brazil.
} 